\title{
VALIDITY OF A DEFENSE THAT THE DEFEND- ANT WAS NOT SATISFIED, IN CASES OF CONTRACT WHEREIN IT WAS SPECIFIED THAT THE STIPULATIONS OF THE OTHER PARTY SHOULD BE PERFORMED TO HIS SATISFACTION.
}

When two parties have entered into a contract, performance by the one is often a necessary preliminary to the maintenance of an action against the other for non-performance. This performance, moreover, must be in accordance with the terms of the contract as construed by the court. For it is the province of the court to determine, by construction, the meaning of an express contract, and, in doing this, the guiding principle is to effectuate the intention of the parties. Express contracts are given a construction which will bring them as near the actual meaning of the parties as the language used permits.

Interesting questions of construction arise when one of the parties to the contractual obligation has undertaken that performance on his part shall be to the satisfaction of the other party. These questions are usually presented when suit is brought upon such a contract, and the party to whom satisfaction was guaranteed sets up as a defense that he was not satisfied. It then devolves upon the court to decide upon the validity of this defense, and this is determined by finding the meaning of provision guaranteeing the defendant's satisfaction, or by construing the contract. Three constructions have been suggested. By the first, the defendant is made the sole judge as to whether the stipulations of the other party have been performed to his satisfaction, and the honesty of his decision cannot be questioned. By the second, the defendant is the sole judge, but his decision must be made honestly and in good faith. The third imposes upon the defendant a duty to act reasonably. Under this the contract is held to be performed to the defendant's satisfaction if the performance would be satisfactory to a reasonable man.

The first of these constructions, although sustained by numerous dicta, seems to lack the support of judicial decision. 
On reviewing the authorities, it is found to be without the direct sanction of a single case. The main contention usually is whether to apply the second or the third construction. By some courts the second construction is always applied, and the defendant's honest judgment is held to determine conclusively the satisfactoriness of the plaintiff's performance. Other courts apply this construction only to contracts made "to gratify taste, serve personal convenience or satisfy individual preferences." 1 The third construction, requiring the defendant to act reasonably, is applied by these courts to all other contracts. From what has been said, it will be readily seen that, in all jurisdictions, contracts containing the personal element above referred to, receive the same construction. It may be well, therefore, to review the cases in which contracts of this nature are construed, before turning to those in which a different rule of construction is applied in different jurisdictions. This review of the authorities is to be, for the most part, illustrative, and the citations are intended to be typical rather than exhaustive.

The case of Zaleski v. Clark ${ }^{2}$ is a good illustration of the construction given a contract falling within the rule applicable to contracts made " to gratify taste, serve personal convenience or satisfy individual preferences." In this case the plaintiff, a sculptor, brought an action for the price of a bust which he had made of the defendant's deceased husband. The bust had been made under a contract which expressly provided that the defendant need not pay the purchase price unless satisfied with it. The defendant was not satisfied because it had not the expression of the deceased during his life, and this was held to be a good defense to the maintenance of the action, although the fault was not the result of imperfect workmanship, but because of the nature of a bust, as a dead white model and necessarily destitute of the expression of color and life. The fact that the defendant ought to have been satisfied, it was held, was immaterial.

Brown v. Foster' is another case of this class. There the plaintiff, a tailor, had agreed to make the defendant a suit of clothes to his satisfaction. The defendant was not satisfied with the clothes and returned them, refusing exen to allow the plaintiff to make alterations. In an action for the price it was

\footnotetext{
1 Danforth, J., Boiler Co. v. Garden et al., Ior N. Y. 390.

${ }^{2} 44$ Conn. 218.

${ }^{8} 113$ Mass. 136. 
proved by other tailors that the clothes were well made, except for a slight defect which could be easily remedied. Nevertheless, it was held that the action would not lie. "Although," said Devens, J., "the compensation of the plaintiff for valuable service and materials may thus be dependent upon the caprice of another who unreasonably refuses to accept the articles manufactured, yet he cannot be relieved from the contract in to which he has voluntarily entered." So also where the plaintiff had " undertaken to make an enlarged picture of the defendant's deceased daughter, and in another case, where the contract was to make a crayon portrait of the defendant and his wife, the same conclusion was reached. In both cases the plaintiff had undertaken that the work should be satisfactory to the defendant, and in both cases the dissatisfaction of the defendant, whether reasonable or not, was held to be a valid defense.

These views are also entertained in England, where it was decided by Cresswell, J., Williams, J., and Willis, J., concurring, that a contract to build a pony-phaeton to meet the defendant's approval, "not only on the score of workmanship, but also that of convenience and taste," gave the defendant a right to reject it, provided he acted bôna fide."

Contracts of service containing a stipulation for satisfaction also seem to belong to this category, whenever the services to be rendered are of a personal nature. And so in New York, where the distinction is made between contracts involving elements of personal taste and convenience and those which do not, it was held that an agent employed for a year, provided he "could fill the place satisfactorily," might be discharged by the employer whenever dissatisfied." The view that this decision, which is followed in a later case, ${ }^{6}$ was based upon the theory that the contract involved was within the rule applicable to contracts made to serve personal taste or convenience, is supported by the opinion of Danforth, J., in Boiler Co. v. Garden." Numerous other cases have included the construction of service contracts of this nature and, wherever the services have been of a personal nature, the conclusion has been the same. ${ }^{10}$

- Gibson v. Cranage, 39 Mich. 49.

3 Moore v. Goodwin, 43 Hun. 534. See also Hoffman v. Galaher, 6 Daly 42. (Friend's satisfaction.)

Andrews v. Belfield, 2 C. B. (N. S.) 779.

T Tyler v. Ames, 6 Lans. (N. Y.) 280.

s Spring v. Clock Co., 24 Hun 175.

- IOI N. Y. 337, 390.

${ }^{10}$ Harder v. Board of Commrs., 97 Ind. 455; Durgin v. Baker, 32 Me. 273. 
But in those jurisdictions which have not a uniform rule of construction it is essential that the services to be rendered are of a personal nature. Otherwise the contract would receive a construction requiring the employer to act as a reasonable man in dismissing the employee. This is well illustrated br two recent New York cases, the facts of which are almost identical. In both of these cases dramatic artists were employed under contracts which reserved to the employer the right to dismiss them, if at any time he should be satisfied, in good faith, that they were incompetent, and in each case it was held that this gave the employer no arbitrary right of dismissal." The opinions in these cases are somewhat involved, because of certain limiting terms in the contracts to be construed, but it seems to have been clearly the intention of the learned judges to keep the construction of contracts for this kind of services without the rule applicable to contracts involving elements of personal taste and convenience. This view, moreover, finds support in the opinion of Andrews, Ch. J., in one of the cases under consideration. $^{12}$ So also a contract to alter certain boilers proyiding for payment when the employer is "satisfied that the boilers as changed are a success," was expressly held not to be within the rule of construction applied when the object of the contract is to "gratify taste, serve personal convenience or satisfy individual preference." 1s

The same principles control service contracts for a definite period, which contain a stipulation that the emploree may leave whenever dissatisfied. In these cases, provided the services are of a personal nature, the employee may quit the employment whenever he is dissatisfied, and recover for services actually rendered, although his departure was before the expiration of his term." The fact that the employee has no good reason for his dissatisfaction is immaterial. ${ }^{16}$

As already indicated, contracts expressly stipulating for satisfaction, but which are not made to gratify taste, serve personal convenience or satisfy individual preference, do not receive the same construction in all jurisdictions. It is in regard to contracts of this nature that the authorities are in conflict, and the contention, above referred to, whether to apply

"Smith v. Robson, 148 N. Y. 252; Grinnell v. Kiralfy, 55 Hun 422.

${ }^{13}$ Smith v. Robson, I48 N. Y. 252, 255-6.

${ }^{13}$ Boiler Co. v. Garden, 1or N. Y. $387,390$.

14 Rossiter v. Cooper, 23 Vt. 522; Provost v. Harwood, 29 Vt 219; Sloan v. Hayden, IIo Mass. I4I; Moffatt v. Dickson, I3 Com. B. 543.

"Rossiter F. Cooper, 23 Vt. 522, 524-5. 
the construction requiring the defendant to act reasonably or that allowing the defendant's judgment, honestly exercised, to determine the satisfactoriness of the plaintiff's performance, is most marked.

The New York courts are the leading exponents of the construction of this class of contracts, by which the defendant is required to act as a reasonable man. This view seems to have been instituted by Kent, Ch. J., in Follard v. Wallace. ${ }^{15}$ In that case the defendant agreed to pay the plaintiff a certain sum if satisfied that the title to a piece of land, conveyed to him by the plaintiff, was undisputed. In a suit upon this contract it was held that dissatisfaction, without some good reason therefor, was no defense; "the 1aw," said the court, "will determine for the defendant when he ought to be satisfied." This decision was followed in a later case where specific performance of a similar contract was granted. ${ }^{17}$ In two very recent cases the same conclusion has been reached and contracts to convey "satisfactory" titles have received a construction requiring the title only to be "marketable." Is It is true that in one case in this jurisdiction it was held that an action for the price of a steamboat sold under a contract containing a stipulation for satisfaction, would not lie unless the vendee was in fact satisfied, and whether or not the vendee ought in reason to have been satisfied was immaterial." This conclusion, however, which has only the sanction of a Supreme Court decision which was not unanimous, is so inharmonious with more recent cases that it may be regarded as virtually overruled. The case of Doll v. Noble ${ }^{20}$ more correctly illustrates the present law of New York. In that case an action was brought to recover money due upon a contract for polishing and staining the woodwork of two houses. It had been provided in the contract that the work should be done "to the entire satisfaction" of the defendant, but this, it was held, gave the defendant no right to defeat a recovery by unreasonably saying that he was not satisfied. The case of Boiler Co. v. Garden ${ }^{21}$ and the two cases construing contracts for services of theatrical performers, ${ }^{32}$ which

" 2 Johns, N. Y. 397 .

"Rigney v. Coles, 6 Bosw. (N. Y.) 479.

${ }^{18} \mathrm{Jay}$ v. Wilson, $9 \mathrm{I}$ Hun 39x; Moot $\mathrm{v}$. Business Men's Investment Ass'n, I57 N. Y. 201.

"Gray v. R. R. Co., II Hun 70.

${ }^{20} 116$ N. Y. 230.

"1 IOI N. Y. 387 .

"Smith v. Robson, I48 N. Y. 252; Grinnell v. Kiralfy, 55 Hun 422. 
have been referred to in another connection, are also good illustrations of the principles now under consideration.

Illinois has adopted a similar construction of contracts of this nature, and in a recent case in that State, a contract to grade some land to the satisfaction of the defendant was held to be performed when the grading was done in a manner satisfactory to the mind of a. reasonable man. ${ }^{23}$ Other views were advanced in an early case, ${ }^{24}$ but these must now be considered repudiated.

In most jurisdictions, however, the rule of construction is uniform. Contracts of this kind receive the same construction that is given contracts involving elements of personal taste and convenience, and the defendant's honest judgment is held to determine whether or not the plaintiff's performance is satisfactory to him. This construction was applied in Massachusetts in the case of McCarren v. McNulty, ${ }^{26}$ where the plaintiff had undertaken to build a book-case for a society, and to finish it in a manner satisfactory to the president of the society. It was decided in this case that, unless the book-case was satisfactory to the president of the society, there could be no recovery for labor and materials; for, from the consequences of the plaintiff's own bargain, the law would afford him no relief. So where a machine for generating gas was sold under a contract providing for the repayment of the purchase price in case the vendee was not satisfied, it was held that, if the vendee was not satisfied, an action by him to recover the purchase price would lie, and it was immaterial that the machine was an excellent one. ${ }^{26}$ In Vermont, also, the same constrction was applied in McClure v. Briggs." In that case the plaintiff's agent set up an organ for the defendant, under an agreement giving to the defendant the right to reject it if not satisfied with it. The defendant honestly thought he was dissatisfed, although without cause, and this, it was held, was a good defense to an action for the price. If the dissatisfaction was real and not feigned, honest and not pretended, the plaintiffs had not fulfilled their contract. The same conclusion was also reached in Vermont, in two earlier cases, one involving the construction of a contract for the sale of a set of milk pans, ${ }^{38}$ the other the construction of

${ }^{23}$ Keeler $\nabla$. Clifford, 165 Ill. 544.

94 Goodrich ४. Van Nortwick, 43 Ill. 445.

${ }^{25} 7$ Gray - 139.

26 Aiken v. Hyde, 99 Mass. 183.

$958 \mathrm{Vt} .82$.

ss Daggett v. Johnson, 49 Vt. 345. 
a contract for the sale of a sugar evaporator, ${ }^{20}$ and both containing a stipulation for satisfaction.

Several recent cases have settled the question in Pennsylvania. In one of these an action was brought to recover the purchase price of a reaper and binder, sold on condition that it should prove satisfactory to the defendant. A charge to the jury that, if the defendant had reasonable cause to be displeased with the machine he had the right to reject it, was held to be erroneous; and it was decided that the defendant had the right to reject it if his objections were made in good faith, and it was immaterial how unreasonable or ill-founded they might appear to others. ${ }^{30}$ This conclusion has been firmly maintained in three other cases in the same jurisdiction. ${ }^{31}$ Similar contracts for the sale of machines have several times come before the courts of Michigan, and in every case have received a construction permitting the defendant, provided he acted in good faith, to be the sole judge as to whether or not the stipulations of the plaintiff had been performed to his satisfaction. ${ }^{32}$ In one of these cases the machine was accidentally burned before the defendant had concluded that it satisfied him. It was, therefore, decided that the loss should fall upon the plaintiff. ${ }^{33}$ So also in Wisconsin, in the case of a similar contract for the sale of exhaust fans to be used in the defendant's blacksmith shops, a demurrer to an answer, setting up that the defendant was honestly and in good faith dissatisfied with the fans, was held to have been properly overruled."

In Virginia it was decided that an action would not lie to compel specific performance of a contract to purchase land, the title to which was to be satisfactory to the vendee, unless the vendee was in fact satisfied with the title; and if the vendee was in good faith not satisfied, it made no difference that the title was really good." Two cases in Maryland, have decided that when a railroad company has contracted to purchase supplies, provided they are satisfactory to certain agents of the

${ }^{29}$ Manufacturing Co. v. Brush, 43 Vt. 528.

${ }^{20}$ Seeley v. Welles, $120 \mathrm{~Pa} .69$.

${ }^{31}$ Boiler Works v. Schmader, I55 Pa. 394; Howard v. Smedley, I40 Pa. 8I; Singerley $\nabla$. Thayer, $108 \mathrm{~Pa} .29 \mathrm{I}$.

${ }^{39}$ Platt v. Broderick, 38 N. W. R. 579 (Mich); Plano Manufacturing Co. v. Ellis, 35 N. W. R. 84 I (MFich.); Pierce v. Cooley, 23 N. W. R. 3 Io (Mich.); Machine Co. v. Smith, 50 Mich. 565.

23 Pierce v. Cooley (supra).

84 Exhaust Ventilator Co. v. Chicago, M. \& St. P. Ry. Co., 66 Wis. 218.

${ }^{85}$ Averett V. Lipscombe, 76 Va. 404 . 
company, the agents designated may, in the exercise of fair and honest judgment, reject the supplies, and the company will not then be liable for the purchase price. ${ }^{36}$ These conclusions have also the support of a decision in Minnesota, ${ }^{37}$ and of dicta in Indiana ${ }^{38}$ and California. ${ }^{39}$

The Federal Courts have given their support to this construction in two well considered cases. In one of these it was held that a fire engine, sold with a warranty that it would be satisfactory to a committee representing the defendant, might be rejected by the defendant if the committee were not satisfied with it. ${ }^{10}$ In the other, after a review of the authorities, a similar decision was made." The courts of England have taken the same view, although there are dicta to the contrary. ${ }^{.3}$ A few decisions, which at first sight seem conflicting, can probably be distinguished." The case of Grafton v. Eastern Counties Railway "1 may be considered a correct illustration of the English law on this subject. In that case the plaintiff had contracted to furnish the defendant with a quantity of coke satisfactory to the defendant's inspecting officer. It was held that a declaration, which failed to allege that the officer was satisfied, was demurrable. In another case an action was brought for work, labor and materials. The defendant's plea alleged a contract which they might terminate if not satisfied. A replication by the plaintiff that the defendants ought reasonably to hare been satisfied was held, on demurrer, to be no answer to the plea." Several earlier decisions are also to the same effect. ${ }^{\text {ts }}$

It has been seen that but three constructions of contracts of this nature have been suggested, and that the first of these, by which the defendant's judgment, honestly or dishonestly exercised, is held to determine whether or not he is satisfied with the plaintiff's performance, is without the support of a single

${ }^{38}$ B. \& O. R. R. Co. v. Brydon, 65 Md. Ig8; Lynn v. B. \& O. R. R. Co., $60 \mathrm{Md} .404$.

${ }^{37}$ Machine Co. v. Chesrown, 33 Minn. 32.

${ }^{3}$ Barlow v. Thompson, 46 Ind. $384,388$.

${ }^{93}$ Hallidie v. Sutter St. R. R. Co., 63 Cal. 575, 576 .

${ }^{\circ}$ Silsby Manufacturing Co. v. Town of Chico, 24 Fed. R. 893.

4 Pringing Press Co. v. Thorp, 36 Fed. R. 414.

48 Brannstein v. Insurance Co., I. B. \& S. 782, 795.

${ }^{43}$ Dalhman v. King, 4 Bing. N.jC. ro5; Brannstein v. Insurance Co. (supra).

\$ 8 Exch. 699.

4 Stadhart v. Lee. 3 B. \& S. 364

45 Ellis v. Mortimer, I Bos. \& Pul. (N. S.) 257.

Taylor v. Brewer, I M. \& S. 290.

Clarke v. Watson, 18 Com. B. (N. S.) 278. 
decision. This construction, moreover, cannot be maintained on principle. In these cases the intention of the parties, the main consideration in construing contracts, is that the defendant shall in fact be satisfied; and the defendant's judgment in no way determines that he is not satisfied, unless that judgment is honestly rendered.

It has been seen that in most jurisdictions, the second construction, which is the same as the first, except that the defendant's judgment must be honest, is applied indiscriminately to all kinds of contracts in which a performance satisfactory to the defendant has been undertaken. It has been seen that in New York, and probably in Illinois, this construction is applied only to contracts made to gratify taste, serve personal convenience or satisfy individual preference. That in all other cases, in these jurisdictions, performance on the part of the plaintiff is held to be to the satisfaction of the defendant if it would be satisfactory to a reasonable man. This modication seems to have resulted from the harshness, which is more apparent than real, of the rule maintained by the weight of authority. It was probably not applied to contracts made to serve personal taste and convenience, because, in contracts of that nature, the intention to satisfy the defendant personally is more conspicuous. Moreover, in these cases the modified rule would be difficult of application, for, in that kind of contracts, reasonable men might differ widely as to what was a satisfactory performance. An objection to the New York view is that it renders the law on the subject somewhat uncertain. It is difficult to determine just what contracts will be held to fall within the rule applied to contracts made to serve personal taste and convenience. Numerous instances might be suggested in which this question would be exceedingly puzzling.

The view maintained by the weight of authority seems, on the whole; more satisfactory. It has, first, the advantage of uniformity. The necessity of nice distinctions is obviated and the law in this connection rendered more certain. Secondly, it is clearly consistent with the principles usually applied in construing contracts. No other intention can be found in the wording of these contracts than that the defendant himself was to be satisfied, and in determining this the defendant's honest judgment is the only available criterion. That others, the jury or the court are satisfied with the plaintiff's performance is immaterial. The language of these contracts in no way indicates that it was the intention of the parties to consider the undertaking to satisfy the defendant performed, until the 
defendant was in fact satisfied. The fact that the defendant was an unreasonable man should not alter the terms of the obligation. It is true that the application of this construction to some cases seems severe to the plaintiff. But, then, the plaintiff need not have made any such contract. He voluntarily entered into the agreement and it is difficult to see why the law should afford him any relief. This construction, moreover, is certainly no more harsh than the general rule of law that impossibility will not excuse the failure to perform contractual obligations. ${ }^{47}$

This view may also be supported by analogy in the construction which is applied to chattel mortgages containing what is known as the "security" or "danger" clause. By this clause it is usually provided that the mortgagee may take possession of the mortgaged property "when he may deem himself insecure." This is construed to give the mortgagee the right of possession when, in good faith, he thinks himself insecure. His opinion must be genuine, but it need not be reasonable. The mortgagee's decision that he is insecure can only be attacked on the ground that it was made fraudulently. ${ }^{40}$

Of course, however, very clear language should be required to support this construction. In doubtful cases a just hesitation should be felt before deciding that payment is left to the will, or even to the idiosyncrasies of the defendant."

4i Paradine v. Jane, Aleyn, 26; Harmony v. Bingham, 12 N. Y. 99.

${ }^{43}$ Thomas on Chattel Mortgages and Conditional Sales, Sec. 29, cases cited.

i) Hawkins v. Graham, 149 Mass., 284.

Grosvenor Nicholas. 